\title{
Influence of insecticides flubendiamide and spinosad on biological activities in tropical black and red clay soils
}

\author{
G. Jaffer Mohiddin • M. Srinivasulu • \\ K. Subramanyam $\cdot$ M. Madakka $\cdot$ D. Meghana $\cdot$ \\ V. Rangaswamy
}

Received: 12 September 2013/ Accepted: 20 November 2013/Published online: 18 December 2013

(C) The Author(s) 2013. This article is published with open access at Springerlink.com

\begin{abstract}
A laboratory experiment has been conducted to investigate the ecological toxicity of flubendiamide and spinosad at their recommended field rates and higher rates $\left(1.0,2.5,5.0,7.5,10.0 \mathrm{~kg} \mathrm{ha}^{-1}\right)$ on cellulase, invertase and amylase in black and red clay soils after 10, 20, 30 and 40-day exposure under controlled conditions in groundnut (Arachis hypogaea L.) soils of Anantapur District, Andhra Pradesh, India. Flubendiamide and spinosad were stimulatory to the activities of cellulase, invertase and amylase at lower concentrations at 10-day interval. The striking stimulation in soil enzyme activities noticed at $2.5 \mathrm{~kg} \mathrm{ha}^{-1}$, persists for 20 days in both soils. Overall, the higher concentrations $\left(5.0-10.0 \mathrm{~kg} \mathrm{ha}^{-1}\right)$ of flubendiamide, and spinosad were toxic or innocuous to cellulase, invertase and amylase activities, respectively. The results of the present study thus, clearly, indicate that application of the insecticides in cultivation of groundnut, at field application rates improved the activities of cellulase, invertase and amylase in soils.
\end{abstract}

\footnotetext{
G. J. Mohiddin $(\varangle) \cdot$ M. Srinivasulu $\cdot$ D. Meghana

V. Rangaswamy

Department of Microbiology, Sri Krishnadevaraya University, Anantapur 515 055, Andhra Pradesh, India

e-mail: jaffermicro@gmail.com

M. Srinivasulu

e-mail: mandalasrinivasulu@yahoo.in

D. Meghana

e-mail: meghanadasetty@gmail.com

V. Rangaswamy

e-mail: rangamanjula@yahoo.com

M. Madakka

Department of Biotechnology and Bioinformatics, Yogi Vemana

University, Kadapa 516 003, Andhra Pradesh, India

e-mail: mekapogu@gmail.com
}

Keywords Enzyme activities · Flubendiamide · Groundnut (Arachis hypogaea L.) soils · Spinosad

\section{Introduction}

In modern agriculture, it has become a common trend to apply different groups of pesticides, either simultaneously or in succession, for effective control of a variety of pests (Quazi et al. 2011). Pesticides are deliberately introduced into agricultural systems with various formulations to protect crops against weeds, insects, fungi and other pests (Yang et al. 2007; Moorman 1989; Singh et al. 1999; Bhuyan et al. 1992; Chu et al. 2008). However, much of the applied pesticides will finally reach the soil often leading to a combined contamination of pesticide residues in the soil environment (Chu et al. 2008), which may affect the growth and activity of soil microbial communities (Singh and Singh 2005), and in turn affect the enzyme activities.

\footnotetext{
K. Subramanyam

Plant Molecular Biology Unit, Department of Biotechnology and Genetic Engineering, Bharathidasan University, Tiruchirappalli 620024, Tamil Nadu, India

e-mail: prasamshika2@gmail.com

M. Srinivasulu

Radioactive Waste Management (Bioremediation) Lab, Division of Advanced Nuclear Engineering, Pohang University of Science and Technology, Pohang-si, Republic of Korea
}

Present Address:

G. J. Mohiddin

Department of Life Sciences and Agriculture, Universidad de las Fuezas Armada, Sangolqui, Quito, Ecuador, South America 
Increasing use of pesticides in agriculture led to the development of soil microbial testing programme for examination of the side effects (Swaminathan et al. 2009). The testing programmes include measurement of activities of soil enzymes, and physicochemical properties.

The economy of India is largely dependent on agricultural production. Better harvest requires rigorous cultivation, irrigation, fertilizers and pesticides to protect plants from pests and plant diseases. In India, 15-20\% of all produce is destroyed by pests (Bhalerao and Puranik 2009). Groundnut (Arachis hypogaea L.) is one of the most important cash crops grown in Indian agricultural soils with the highest yield among the oil seeds' crops (Singh and Singh 2005; Menon et al. 2004; Bera et al. 2002) and is the primary source of edible oil in India (Ramesh babu et al. 2002). India is a world leader in groundnut farming, with 6.0 million hectares of the cultivated area during the year 2010-11 (USDA 2011). Within India, Andhra Pradesh State ranks first in area and production (Hegde and Kiresur 1999). Among different regions of Andhra Pradesh, Anantapur District, a semiarid region relies on groundnut cultivation, predominantly (Anonymous 2011). In spite of its high range of cultivation, groundnut productivity is low, fluctuating around $9 \mathrm{q} / \mathrm{ha}$ on average, and an annual yield loss of Rs. 150 crores due to pests has been reported (Loganathan et al. 2002). Among the pesticides, insecticides of flubendiamide and spinosad are in the current list of modern pesticides in Indian agriculture used to control incidence of pest attack over groundnut crop.

Soil is a natural system containing microbes which are the driving force behind many soil processes, including transformation of organic matter, nutrient release and degradation of xenobiotics (Zabaloy et al. 2008). Many studies have shown that biological parameters have been used to assess soil quality and health as affected by agricultural practices (Gianfreda et al. 2005; Truu et al. 2008; Garcia-Ruiz, et al. 2009). In this respect, soil enzymes can be used as potential indicators of soil quality for sustainable management because they are sensitive to ecological stress and land management practices (Tejada 2009). Flubendiamide represents a novel class of insecticides with extremely high activity against a broad spectrum of lepidopterous insects (Tohnishi et al. 2005). Spinosad is a biologically derived insecticide that consists of two active compounds, spinosyns A and D, produced by fermentation culture of an actinomycete isolated from soil (Saccharopolyspora spinosa Mertz and Yao). Structurally, these compounds are macrolides and contain a unique tetracycling system to which two different sugars are attached (Kirst et al. 1992). Negative impact of pesticides on soil enzymes activities has been widely reported throughout the literature (Ismail et al. 1998; Menon et al. 2005) unfortunately no reports were available on these two new insecticides on enzyme activities.

The quorum-sensing systems allow bacteria to monitor their environment for the presence of other bacteria and to respond to fluctuations in the number and/or species present by altering particular behaviors. Most quorum-sensing systems are species- or group-specific, which presumably prevents confusion in mixed-species environments. However, some quorum-sensing circuits control behaviors that involve interactions among bacterial species. These quorum-sensing circuits can involve both intra- and interspecies communication mechanisms. Finally, anti-quorum-sensing strategies are present in both bacteria and eukaryotes and these are apparently designed to combat bacteria that rely on cell-cell communication and for the successful adaptation to particular niches. Many enzymes of both microbial or plant origins have been recognized to be able to transform pollutants at a detectable rate and potentially suitable to restore polluted environment. The main enzymatic classes involved in such a process are hydrolases, dehalogenases, and oxidoreductases. Amide, ester and peptidic bonds undergo hydrolytic cleavage by amidases, esterases and proteases in several xenobiotic compounds and may lead to products with little or no toxicity. Hydrolases responsible for the cleavage of pesticides are among the best studied groups of enzymes. Most of these hydrolases are extracellular enzymes, except for the cell wall-bound enzymes of penicillium and arthrobacter sp., which hydrolyze barban and propham.

Cellulase can catalyze hydrolysis of 1,4 , beta- D-glycosidic bonds of cellulose and is also an important indicator for carbon circulation. Invertase is known to be a very stable and persistent enzyme, and its association with soil components is well documented (Kiss et al. 1978). Amylase plays an important role in biochemical reactions and nutrient cycling. Apparently, it has become necessary to determine the effects of agronomically needed pesticides (flubendiamide and spinosad), applied at recommended levels and at higher doses, in order to establish the significance, in terms of biogeochemical reactions and nutrient cycling. Hence the present study was carried out to determine the influence of insecticides on the activity of cellulase, invertase and amylase in two groundnut soils of Anantapur district, Andhra Pradesh, India from December 2, 2010 to July $15,2011$.

\section{Materials and methods}

\section{Soils}

Black and red clay soils were used in the present study. Soil samples taken from groundnut-cultivated fields of Anantapur district, Andhra Pradesh, India, were chosen 
with a known history of pesticides use, from a depth of $12 \mathrm{~cm}$, air-dried and sieved through $2 \mathrm{~mm}$ sieve before usage. Mineral matter of soil samples such as sand, silt, and clay contents were analyzed with use of different sizes of sieves by following the method of Alexander (1961). Cent percent water-holding capacity of soil samples was measured by finding amount of distilled water added to both the soil samples to get saturation point and then $60 \%$ waterholding capacity of soil was calculated by the Johnson and Ulrich method (1960). Soil $\mathrm{pH}$ was measured at 1:1.25 soil-to-water ratio in a Systronics digital $\mathrm{pH}$ meter with calomel glass electrode assembly. Organic carbon content in soil samples was estimated by Walkley-Black method, and the organic matter was calculated by multiplying the values with 1.72 (Jackson 1971). Electrical conductivity of soil samples after addition of $100 \mathrm{ml}$ distilled water to $1 \mathrm{~g}$ soil samples was measured by a conductivity bridge. Total nitrogen content in soil samples was determined by the method of micro-Kjeldahl method (Jackson 1971). Content of inorganic ammonium-nitrogen in soil samples after extraction of $1 \mathrm{M} \mathrm{KCl}$ by Nesslerization method (Jackson 1971), contents of nitrite-nitrogen (Barnes and Folkard 1951) and contents of nitrate-nitrogen by Brucine method (Ranney and Bartlett 1972) after extraction with water were determined, respectively. Physicochemical characteristics of the two soils are listed in Table 1.

\section{Insecticides}

In order to determine the influence of selected insecticides on the microbial activities, commercial grades of

Table 1 Physicochemical properties of the soils

\begin{tabular}{|c|c|c|}
\hline Properties & Black clay soil & Red clay soi \\
\hline Sand $(\%)$ & 68.45 & 53.25 \\
\hline Silt $(\%)$ & 21.45 & 27.12 \\
\hline Clay $(\%)$ & 10.0 & 19.8 \\
\hline $\mathrm{pH}^{\mathrm{a}}$ & 7.8 & 6.7 \\
\hline Water holding capacity ( $\mathrm{ml} \mathrm{g}^{-1}$ soil) & 0.7 & 0.4 \\
\hline Electrical conductivity (mmhos) & 258 & 232 \\
\hline Organic matter $(\%)^{\mathrm{b}}$ & 1.34 & 0.74 \\
\hline Total nitrogen $(\%)^{\mathrm{c}}$ & 0.086 & 0.038 \\
\hline $\mathrm{NH}_{4}^{+}-\mathrm{N}\left(\mu \mathrm{g} \mathrm{g}^{-1} \text { soil }\right)^{\mathrm{d}}$ & 6.96 & 6.01 \\
\hline $\mathrm{NO}_{2}{ }^{-}-\mathrm{N}\left(\mu \mathrm{g} \mathrm{g}^{-1} \text { soil }\right)^{\mathrm{e}}$ & 0.58 & 0.42 \\
\hline $\mathrm{NO}_{3}{ }^{-}-\mathrm{N}\left(\mu \mathrm{g} \mathrm{g}^{-1} \text { soil }\right)^{\mathrm{f}}$ & 0.94 & 0.73 \\
\hline
\end{tabular}

a $1: 1.25=$ soil:water slurry

b Walkley-Black method (Johnson and Ulrich 1960)

c Micro-Kjeldahl method (Johnson and Ulrich 1960)

${ }^{d}$ Nesslerization method (Johnson and Ulrich 1960)

e Diazotization method (Ranney and Bartlett 1972)

${ }^{\mathrm{f}}$ Brucine method (Barnes and Folkard 1951) flubendiamide and spinosad were obtained from Bayer's Science India.

Soil treatment

The soil ecosystem stimulating non-flooded portions of the soil samples were added in test tubes $(25 \times 150 \mathrm{~mm})$ and moistened with water in order to maintain at $60 \%$ waterholding capacity. Same model was used previously to elucidate the effect of insecticides on microbial activities by Mohiddin et al. (2011).

Cellulase (EC 3.2.1.4), invertase activity (EC 3.2.1.26) and amylase activity (EC 3.2.1.1)

Five-gram portion of the soil samples was weighed and dispersed into sterile test tubes $(25 \times 150 \mathrm{~mm})$. Stock solutions from selected insecticides were added to the rate of $10,25,50,75$ and $100 \mu \mathrm{g} \mathrm{g}^{-1}$ soil equivalent to field application rates of $1.0,2.5,5.0,7.5$ and $10.0 \mathrm{~kg} \mathrm{ha}^{-1}$ respectively. Soil samples without insecticide treatment served as controls. Soil samples were mixed thoroughly for uniform distribution of insecticide that was added. Triplicates were maintained for each treatment at room temperature $\left(28 \pm 4{ }^{\circ} \mathrm{C}\right)$ with $60 \%$ water-holding capacity throughout the incubation period. After desired intervals of incubation, soil samples were extracted in distilled water for estimation of enzyme activities. Similar model was used earlier by (Singaram and Kamalakumari 2010; Mohiddin et al. 2010).

In order to determine cellulase enzyme activity in soils, the method employed for the assay of cellulase was developed by Cole (1977) and followed by Tu (1981a, b). The soil samples were transferred to $100 \mathrm{ml}$ Erlenmeyer flasks and were treated with $1 \mathrm{ml}$ of toluene to arrest the enzyme activity. After $15 \mathrm{~min}, 10 \mathrm{ml}$ of carboxy methyl cellulose (CMC) $1 \%$ was used as a substrate followed by $10 \mathrm{ml}$ of acetate buffer ( $\mathrm{pH} \mathrm{5.9)}$ and incubated for $24 \mathrm{~h}$ to determine the reducing sugar content in the filtrate (Deng and Tabatabai 1994). In another experiment, cellulase activity was determined at 10,20, 30 and 40 days of soil incubation. Testing samples were passed through Whatman No. 1 filter paper and the filtrate was assayed for the amount of glucose by the Nelson method (1944) in a Spectronic 20 D spectrophotometer.

The method employed for assay of invertase was developed by Cole (1977) and followed by (Tu 1981a, b). The soil samples were transferred to $100 \mathrm{ml}$ Erlenmeyer flasks and treated with $1 \mathrm{ml}$ toluene to arrest the enzyme activity. After $15 \mathrm{~min}, 6 \mathrm{ml}$ of $18 \mathrm{mM}$ sucrose was added to the soil samples and incubated for 24 and $48 \mathrm{~h}$; the testing samples were passed through Whatman No. 1 filter paper and the filtrate was assayed for the amount of glucose 
by the Nelson method (1944) in a Spectronic 20 D spectrophotometer.

The method employed for the assay of amylase was developed by Cole (1977) and followed by Tu (1981a, b). The soil samples were transferred to $100 \mathrm{ml}$ Erlenmeyer flasks and treated with $1 \mathrm{ml}$ toluene to arrest the enzyme activity. After $15 \mathrm{~min}, 6 \mathrm{ml}$ of $0.2 \mathrm{M}$ of acetate phosphate buffer $(5.5 \mathrm{pH})$ containing $2 \%$ starch was added to each of the testing samples and closed with cotton plugs. After 24 and $72 \mathrm{~h}$ of incubation, the testing samples were made up to a volume of $50 \mathrm{ml}$ with sterile distilled water and passed through Whatman No. 1 filter paper and the filtrate was assayed for the amount of glucose by Nelson's method (1944) in a Spectronic 20 D spectrophotometer.

\section{Statistical analysis}

The concentration of the cellulase, invertase and amylase was calculated based on soil weight (oven dried). Data were analyzed using one-way ANOVA, and the differences contrasted using Duncan's multiple range test (DMRT) (Megharaj et al. 1999; Mohiddin et al. 2011). All statistical analyses were performed at $P \leq 0.05$ using SPSS statistical software package.

\section{Results and discussion}

The black and red clay soils are predominantly used for the cultivation of groundnut (Arachis hypogaea L.) in the Anantapur district of Andhra Pradesh, India. The major constraints in the groundnut crop are insects and fungi pests. For this reason, pesticides are frequently used for crop protection. Continuous and indiscriminate use of these pesticides causes a major risk of soil health. Hence, these soils were selected to study the effect of insecticides on enzyme activities. In general, the organic matter content is high in black soil. Therefore, the biological activity was also pronounced more in black soil than in red soil under the influence of insecticides. There have been many reports of the effects of pesticides on soil enzyme activities (Anonymous 2011; Loganathan et al. 2002) and it has been
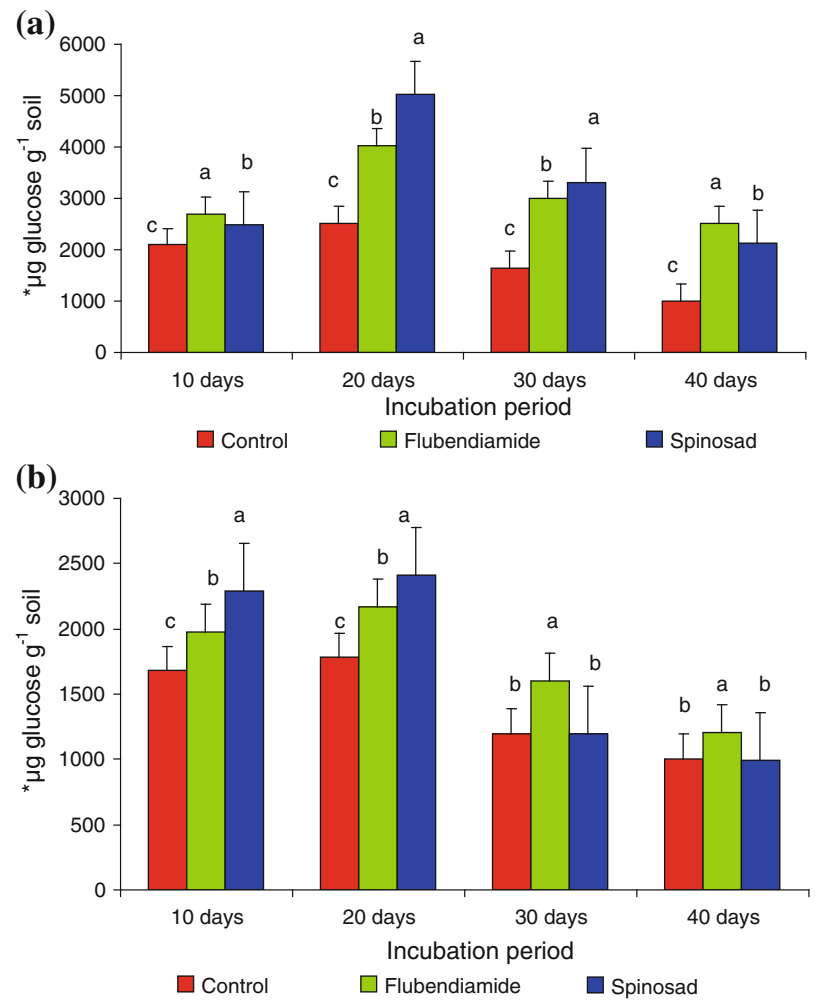

Fig. 1 Influence of flubendiamide and spinosad on cellulase*activity in a black clay and $\mathbf{b}$ red clay soil at $2.5 \mathrm{~kg} \mathrm{ha}^{-1}$. ${ }^{*} \mu \mathrm{g}$ glucose per gram soil formed after $24 \mathrm{~h}$ incubation with Carboxy methyl cellulose (CMC). The values are the mean $\pm \mathrm{SE}$ for each incubation period, are not significantly different $(P \leq 0.05)$ from each other according to Duncan's multiple range (DMR) test

Table 2 Activity of cellulase under the impact of different concentrations of flubendiamide and spinosad in black and red clay soils for $24 \mathrm{~h}$ after 10 days

\begin{tabular}{|c|c|c|c|c|}
\hline \multirow{2}{*}{$\begin{array}{l}\text { Concentration of } \\
\text { insecticides }\left(\mathrm{kg} \mathrm{ha}^{-1}\right)\end{array}$} & \multicolumn{2}{|l|}{ Black clay soil } & \multicolumn{2}{|l|}{ Red clay soil } \\
\hline & $\begin{array}{l}\text { Flubendiamide } \\
24 \mathrm{~h}\end{array}$ & $\begin{array}{l}\text { Spinosad } \\
24 \mathrm{~h}\end{array}$ & $\begin{array}{l}\text { Flubendiamide } \\
24 \mathrm{~h}\end{array}$ & $\begin{array}{l}\text { Spinosad } \\
24 \mathrm{~h}\end{array}$ \\
\hline 0.0 & $2,090 \pm 5.773 \mathrm{c}(100)$ & $2,090 \pm 5.773 \mathrm{c}(100)$ & $1,680 \pm 11.547 \mathrm{c}(100)$ & $1,680 \pm 11.547 \mathrm{~d}(100)$ \\
\hline 1.0 & $2,400 \pm 57.735 \mathrm{~b}(115)$ & $2,330 \pm 17.320 \mathrm{~b}(134)$ & $1,720 \pm 5.773 \mathrm{~b}(102)$ & $1,880 \pm 11.547 \mathrm{c}(112)$ \\
\hline 2.5 & $2,700 \pm 2.886$ a (129) & $2,490 \pm 2.886$ a $(172)$ & $1,980 \pm 0.577$ a (118) & $2,290 \pm 4.041$ a $(136)$ \\
\hline 5.0 & $1,700 \pm 17.320 \mathrm{~d}(81)$ & $1,350 \pm 5.773 \mathrm{~d}(134)$ & $1,400 \pm 17.320 \mathrm{~d}(83.3)$ & $2,200 \pm 57.735$ b (130) \\
\hline 7.5 & $1,390 \pm 4.041$ e $(66)$ & $1,190 \pm 0.577 \mathrm{f}(128)$ & $1,090 \pm 2.309$ e $(65)$ & $1,200 \pm 25.980$ e $(71)$ \\
\hline 10.0 & $1,100 \pm 5.773 \mathrm{f}(52)$ & $1,250 \pm 3.464$ e $(60)$ & $990 \pm 1.732 \mathrm{f}(97)$ & $1,120 \pm 14.433 \mathrm{f}(67)$ \\
\hline
\end{tabular}

$\mu \mathrm{g}$ glucose per gram soil formed after $24 \mathrm{~h}$ of incubation with $1 \%$ carboxy methyl cellulose (CMC)

Each column is mean \pm SE for six concentrations in each group; columns not sharing a common letter (a, b, c, d, e and f) differ significantly with each other $(P \leq 0.05$; DMRT $)$ 
observed that the responses of soil enzymes to different pesticides are not the same. As a new pesticide, unfortunately, there is no information available regarding the influence of flubendiamide and spinosad on soil enzyme activities. Of course, when the flubendiamide and spinosad concentration was increased, the potential hazard to soil would increase. Soil enzyme activities are more sensitive to the environment. They reflect the soil quality more quickly and directly (Srinivasulu et al. 2012).

Since enzyme activity has been considered as a very sensitive indicator, any disturbance due to biotic or environmental stresses in the soil ecosystem may affect soil biological properties. Our analysis revealed that cellulase activity was significantly increased from 0.1 to $2.5 \mathrm{~kg} \mathrm{ha}^{-1}$ whereas the activity was decreased at higher concentrations (5.0-10.0 $\mathrm{kg} \mathrm{ha}^{-1}$ ) of pesticides in both soils (Table 2). The cellulase activity was significantly enhanced at $2.5 \mathrm{~kg} \mathrm{ha}^{-1}$ level in both soils for flubendiamide and spinosad and showed individual increments of cellulase activity ranging from a low increase 15-29, 11-19 and $2-18,12-36 \%$ in comparison to control (Table 2). The stimulatory concentration $\left(2.5 \mathrm{~kg} \mathrm{ha}^{-1}\right)$ induces the highest cellulase activity after 20,30 and 40 days of incubation in black clay soils (Fig. 1a) with flubendiamide and spinosad when compared to control. Whereas in red clay soil a similar trend was followed by flubendiamide, induces the highest cellulase activity after 20,30 and 40 days of incubation but spinosad showed a variable pattern was observed at 30 and 40 days, the cellulase enzyme activity remained same with control (Fig. 1b). The relatively low activity of cellulase might result from the toxic effect of flubendiamide and spinosad on soil microorganisms, which in turn produces cellulase. The inhibition of cellulase activity by flubendiamide and spinosad could be attributed to the properties of flubendiamide and spinosad. Similar type of reports were identified by (Ramudu et al. 2011; Mohiddin et al. 2010) chlorothalonil and propiconazole, imidacloprid, and acephate. Similar observations were made by Katayama and Kuwatsuka (1991) and Jaya Madhuri and Rangaswamy (2002) on the cellulase activity. Analogous report was obtained by Ismail et al. (1996a, b) on application of metolachor to Malaysian soil. Gigliotti

Table 3 Activity of invertase under the impact of different concentrations of flubendiamide and spinosad in black clay soil for 24 and $48 \mathrm{~h}$ after 10 days

\begin{tabular}{|c|c|c|c|c|}
\hline \multirow{2}{*}{$\begin{array}{l}\text { Concentration of } \\
\text { insecticides }\left(\mathrm{kg} \mathrm{ha}^{-1}\right)\end{array}$} & \multicolumn{2}{|l|}{ Flubendiamide } & \multicolumn{2}{|l|}{ Spinosad } \\
\hline & $24 \mathrm{~h}$ & $48 \mathrm{~h}$ & $24 \mathrm{~h}$ & $48 \mathrm{~h}$ \\
\hline 0.0 & $900 \pm 0.577$ c (100) & $950 \pm 2.309$ e $(100)$ & $900 \pm 0.577$ c (100) & $950 \pm 2.309$ e $(100)$ \\
\hline 1.0 & $915 \pm 2.886$ b (102) & $960 \pm 5.773 \mathrm{~d}(101)$ & $900 \pm 0.577 \mathrm{~b}(100)$ & $1,780 \pm 11.547$ c $(187)$ \\
\hline 2.5 & $1,520 \pm 5.773$ a (169) & $1,650 \pm 4.618$ a (174) & $1,620 \pm 4.618$ a $(180)$ & $1,900 \pm 17.320$ a $(200)$ \\
\hline 5.0 & $800 \pm 5.773 \mathrm{~d}(89)$ & $1,310 \pm 1.732 \mathrm{~b}(138)$ & $600 \pm 0.577 \mathrm{~d}(67)$ & $1,850 \pm 5.773 \mathrm{~b}(195)$ \\
\hline 7.5 & $750 \pm 3.464$ e $(83)$ & $980 \pm 11.547$ c (103) & $440 \pm 23.094$ e (49) & $1,060 \pm 3.464 \mathrm{~d}(111)$ \\
\hline 10.0 & $700 \pm 1.732 \mathrm{f}(78)$ & $800 \pm 5.773 \mathrm{f}(84)$ & $400 \pm 2.886 \mathrm{f}(44)$ & $900 \pm 0.577 \mathrm{f}(95)$ \\
\hline
\end{tabular}

$\mu \mathrm{g}$ glucose per gram soil formed after $24 \mathrm{~h}$ of incubation with $18 \mathrm{Mm}$ sucrose

Each column is mean $\pm \mathrm{SE}$ for six concentrations in each group; columns not sharing a common letter (a, b, c, d, e and f) differ significantly with each other $(P \leq 0.05$; DMRT $)$

Table 4 Activity of invertase under the impact of different concentrations of flubendiamide and spinosad in red clay soil for 24 and $48 \mathrm{~h}$ after 10 days

\begin{tabular}{|c|c|c|c|c|}
\hline \multirow{2}{*}{$\begin{array}{l}\text { Concentration of } \\
\text { insecticides }\left(\mathrm{kg} \mathrm{ha}^{-1}\right)\end{array}$} & \multicolumn{2}{|l|}{ Flubendiamide } & \multicolumn{2}{|l|}{ Spinosad } \\
\hline & $24 \mathrm{~h}$ & $48 \mathrm{~h}$ & $24 \mathrm{~h}$ & $48 \mathrm{~h}$ \\
\hline 0.0 & $420 \pm 4.618 \mathrm{f}(100)$ & $800 \pm 8.660 \mathrm{~d}(100)$ & $420 \pm 4.618 \mathrm{~d}(100)$ & $800 \pm 5.773 \mathrm{f}(100)$ \\
\hline 1.0 & $600 \pm 0.577 \mathrm{~d}(143)$ & $1,020 \pm 4.618 \mathrm{~b}(127)$ & $580 \pm 11.547 \mathrm{~b}(138)$ & $1,320 \pm 4.041 \mathrm{~d}(165)$ \\
\hline 2.5 & $760 \pm 4.041 \mathrm{a}(181)$ & $1,120 \pm 11.547$ a $(140)$ & $600 \pm 0.577$ a (143) & $1,800 \pm 0.577$ a $(225)$ \\
\hline 5.0 & $700 \pm 1.732 \mathrm{~b}(166)$ & $920 \pm 4.618 \mathrm{c}(115)$ & $589 \pm 11.547 \mathrm{~b}(140)$ & $1,720 \pm 11.547 \mathrm{c}(215)$ \\
\hline 7.5 & $650 \pm 28.867 \mathrm{c}(155)$ & $780 \pm 11.547$ e $(97)$ & $490 \pm 2.886 \mathrm{c}(117)$ & $1,620 \pm 5.773 \mathrm{~b}(202)$ \\
\hline 10.0 & $620 \pm 11.547$ e $(148)$ & $670 \pm 17.320 \mathrm{f}(84)$ & $350 \pm 10.392$ e $(83)$ & $1,300 \pm 2.886$ e $(162)$ \\
\hline
\end{tabular}

$\mu \mathrm{g}$ glucose per gram soil formed after $24 \mathrm{~h}$ of incubation with $18 \mathrm{Mm}$ sucrose

Each column is mean $\pm \mathrm{SE}$ for six concentrations in each group; columns not sharing a common letter (a, b, c, d, e and f) differ significantly with each other $(P \leq 0.05$; DMRT $)$ 
et al. (1998) also reported that bensulfurn methyl at 16 and $160 \mu \mathrm{g} / \mathrm{g}$ inhibited cellulase activity in soil samples. In a diverse study made by Gherbawy and Abdelzaher (1999),
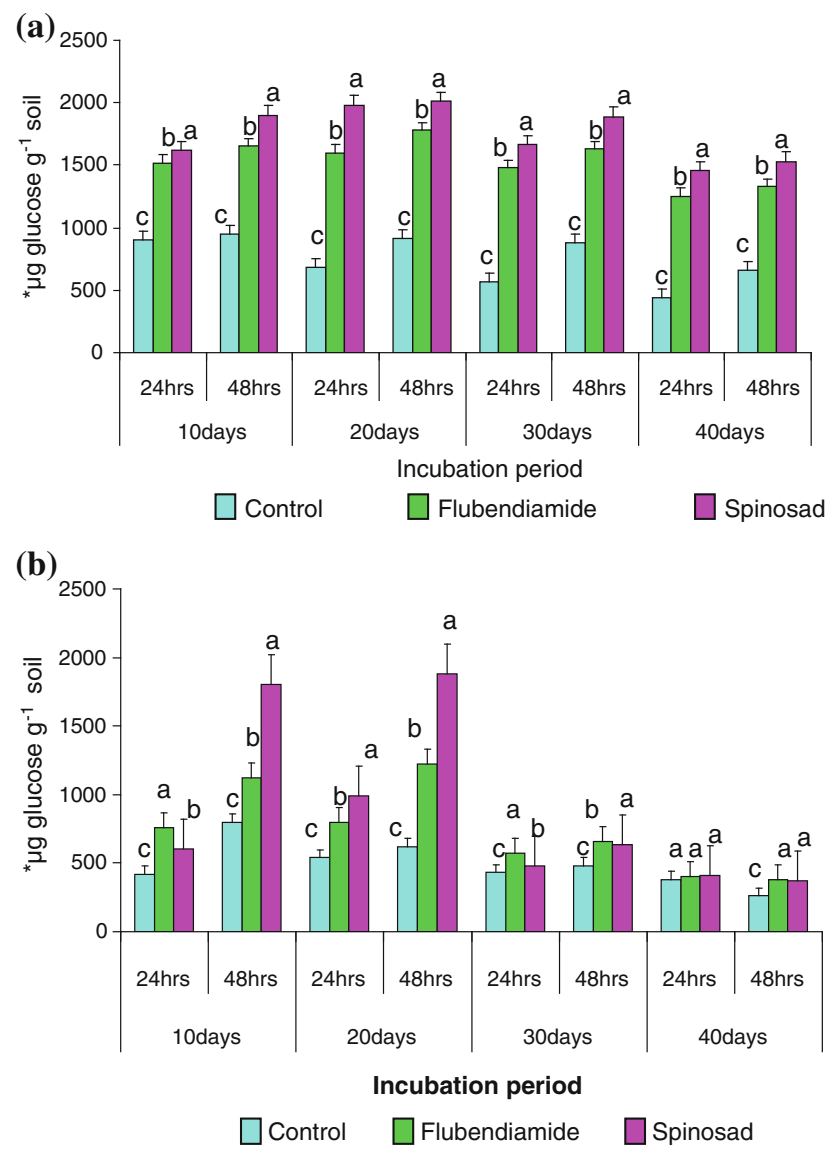

Fig. 2 Influence of flubendiamide and spinosad on invertase*activity in a black clay and b red clay soil at $2.5 \mathrm{~kg} \mathrm{ha}^{-1}$. $* \mu$ g glucose per gram soil formed after 24 and $48 \mathrm{~h}$ incubation with $18 \mathrm{Mm}$ sucrose. The values are the mean $\pm \mathrm{SE}$ for each incubation period, are not significantly different $(P \leq 0.05)$ from each other according to Duncan's multiple range (DMR) test alteration in the activity of cellulase by metalaxyl was marked in pure fungal cultures. Similar results were obtained by Arinz and Yubedee (2000) that kelthane and fenvalerate caused inhibition to enzyme activity.

Invertase activity was depressed in flubendiamide and spinosad treated soils throughout the experiment when compared to the controls in both soils incubated for 10 days (Tables 3,4 ) The maximum activity was observed at $2.5 \mathrm{~kg} \mathrm{ha}^{-1}$ (stimulatory) for flubendiamide and spinosad showed individual increments of invertase activity ranged from a low increase 2-69, $1-74 \%$ and $0-80$, $87-100 \%$ for black clay soil and for red clay soil, 43-81, $27-40 \%$ and $38-43,65-125 \%$ received $2.5 \mathrm{~kg} \mathrm{ha}^{-1}$ respectively in comparison to control at 24 and for $48 \mathrm{~h}$ (Tables 3,4). The results reveal that invertase enzyme is rather sensitive to flubendiamide and spinosad. Figure 2 showed the variation of invertase activity after flubendiamide and spinosad application. Although enzyme activities of samples were lower than that of control, significant differences $(P \leq 0.05)$ were found among the enzyme activities between treated soil samples and the control (Tables 3, 4). With the increase in incubation periods, the stimulated enzyme activities were also increased up to 20-days further increase in the incubation decrease in the enzyme activity was noticed (Fig. 2a, b). Our results appeared to be consistent with previous reports, in which it is demonstrated that pesticides stimulated invertase activity of soils (Ramudu et al. 2011; Sannino and Gianfreda 2001; Srinivasulu and Rangaswamy 2006). Rate of invertase activity followed the same trend of initial stimulation followed by inhibition as reported by Rangaswamy and Venkateswarlu (1992). On the contrary, Tu (1995) affirmed initial inhibition followed by recovery with five insecticides in sandy loam soil.

Amylase activity (Tables 5,6) showed a variable pattern in response to different insecticide concentration after

Table 5 Activity of amylase under the impact of different concentrations of flubendiamide and spinosad in red clay soil for 24 and $72 \mathrm{~h}$ after 10 days

\begin{tabular}{|c|c|c|c|c|}
\hline \multirow{3}{*}{$\begin{array}{l}\text { Concentration of } \\
\text { insecticides }\left(\mathrm{kg} \mathrm{ha}^{-1}\right)\end{array}$} & \multicolumn{4}{|l|}{ Red clay soil } \\
\hline & \multicolumn{2}{|l|}{ Flubendiamide } & \multicolumn{2}{|l|}{ Spinosad } \\
\hline & $24 \mathrm{~h}$ & $72 \mathrm{~h}$ & $24 \mathrm{~h}$ & $72 \mathrm{~h}$ \\
\hline 0.0 & $180 \pm 2.886 \mathrm{~d}(100)$ & $260 \pm 2.886 \mathrm{~d}(100)$ & $180 \pm 2.886 \mathrm{~d}(100)$ & $260 \pm 2.886 \mathrm{c}(100)$ \\
\hline 1.0 & $290 \pm 2.309 \mathrm{~b}(161)$ & $340 \pm 5.773 \mathrm{~b}(131)$ & $250 \pm 5.773 \mathrm{~b}(139)$ & $300 \pm 0.577 \mathrm{~b}(115)$ \\
\hline 2.5 & $420 \pm 1.732$ a (233) & $520 \pm 0.577$ a $(200)$ & $270 \pm 1.732$ a (150) & $480 \pm 2.309$ a $(185)$ \\
\hline 5.0 & $200 \pm 2.309$ c (111) & $280 \pm 17.320 \mathrm{c}(108)$ & $200 \pm 0.577$ c $(111)$ & $300 \pm 2.309 \mathrm{~b}(115)$ \\
\hline 7.5 & $160 \pm 2.309$ e $(89)$ & $200 \pm 0.577$ e $(77)$ & $205 \pm 2.886$ c (114) & $265 \pm 2.886 \mathrm{c}(102)$ \\
\hline 10.0 & $120 \pm 5.773 \mathrm{f}(67)$ & $180 \pm 11.547 \mathrm{f}(69)$ & $180 \pm 2.886 \mathrm{~d}(100)$ & $250 \pm 5.773 \mathrm{~d}(96)$ \\
\hline
\end{tabular}

$\mu \mathrm{g}$ glucose per gram soil formed after 24 and $72 \mathrm{~h}$ of incubation with $2 \%$ starch

Each column is mean $\pm \mathrm{SE}$ for six concentrations in each group; columns not sharing a common letter (a, b, c, d and e) differ significantly with each other $(P \leq 0.05$; DMRT $)$ 
Table 6 Activity of amylase under the impact of different concentrations of flubendiamide and spinosad in black clay soil for 24 and $72 \mathrm{~h}$ after 10 days

\begin{tabular}{|c|c|c|c|c|}
\hline \multirow{3}{*}{$\begin{array}{l}\text { Concentration of } \\
\text { insecticides }\left(\mathrm{kg} \mathrm{ha}^{-1}\right)\end{array}$} & \multicolumn{4}{|l|}{ Black clay soil } \\
\hline & \multicolumn{2}{|l|}{ Flubendiamide } & \multicolumn{2}{|l|}{ Spinosad } \\
\hline & $24 \mathrm{~h}$ & $72 \mathrm{~h}$ & $24 \mathrm{~h}$ & $72 \mathrm{~h}$ \\
\hline 0.0 & $310 \pm 5.773 \mathrm{~d}(100)$ & $380 \pm 2.886$ e $(100)$ & $310 \pm 5.773$ b (100) & $380 \pm 2.886 \mathrm{c}(100)$ \\
\hline 1.0 & $420 \pm 0.577 \mathrm{~b}(135)$ & $490 \pm 5.773$ c (129) & $310 \pm 11.547 \mathrm{~b}(100)$ & $450 \pm 17.320 \mathrm{~d}(118)$ \\
\hline 2.5 & $500 \pm 8.660$ a $(161)$ & $600 \pm 11.547$ a (158) & $450 \pm 5.773$ a (145) & $570 \pm 1.154$ a (150) \\
\hline 5.0 & $450 \pm 2.886 \mathrm{~b}(145)$ & $520 \pm 1.154$ b (137) & $300 \pm 0.577 \mathrm{~b}(97)$ & $400 \pm 5.773 \mathrm{~b}(105)$ \\
\hline 7.5 & $350 \pm 17.320 \mathrm{c}(113)$ & $460 \pm 2.309 \mathrm{~d}(121)$ & $250 \pm 2.886 \mathrm{c}(81)$ & $305 \pm 1.154$ e $(80)$ \\
\hline 10.0 & $210 \pm 5.773$ e $(67)$ & $320 \pm 5.773 \mathrm{f}(84)$ & $240 \pm 5.773$ c (77) & $280 \pm 1.154 \mathrm{f}(74)$ \\
\hline
\end{tabular}

$\mu \mathrm{g}$ glucose per gram soil formed after 24 and $72 \mathrm{~h}$ of incubation with $2 \%$ starch

Each column is mean \pm SE for six concentrations in each group; columns not sharing a common letter (a, b, c, d and e) differ significantly with each other $(P \leq 0.05$; DMRT $)$

10 days of incubation. Amylase activity increased under lower doses and decreased under higher doses compared to the controls in black and red clay soils. The maximum activity was observed at $2.5 \mathrm{~kg} \mathrm{ha}^{-1}$ (stimulatory) for flubendiamide, spinosad. Amylase activity showed an individual increment of 35-61, 29-58, 0-45, 8-50\%, in black clay soil and $61-133,31-100,39-50,15-85 \%$, in comparison to control at 24 and for $72 \mathrm{~h}$ received 2.5 and $5.0 \mathrm{~kg} \mathrm{ha}^{-1}$ respectively in red clay soil. With the increase in incubation periods, the stimulated enzyme activities were also increased up to 20-days further increase in the incubation decrease in the enzyme activity was noticed (Fig. 3). Our results were in contrast with the several researcher works (Srinivasulu and Rangaswamy 2006; Mohiddin et al. 2010; Tu 1981a, b, 1982, 1988), triazophos, a phosphorothioate triazole is stimulated for amylase at 5 and $10 \mathrm{mg} / \mathrm{kg}$ incubated for 3 days in an organic soil. As per the observation made by the Prasad and Mathur (1983) the amylase activity increased during germination in both control, and Cuman treated seeds at 0.25, 0.5, 0.75 and $1 \%$ respectively. Interaction effects on soil enzyme activities, including amylase activity received least attention. There were only isolated reports on interaction effects between two chemical compounds in axenic culture studies with algae, cyanobacteria and fungi (Megharaj et al. 1989; Stratton and Corke 1982a, b). Kennedy and Arathan (2002) reported that application of carbofuran at 1 and $1.5 \mathrm{~kg} \mathrm{ha}^{-1}$ significantly reduced the activity of soil enzymes, viz., alpha -amylase, beta -glucosidase, cellulase, urease and phosphatase up to 30 days after carbofuran application. However, application of carbofuran at the recommended level $\left(0.5 \mathrm{~kg}\right.$ a.i. $\left.\mathrm{ha}^{-1}\right)$ had no significant effect upon the activity of soil enzymes, which are biologically significant as they play an important role not only in the soil chemical and biological properties but also affect the nutrient availability to plants. Rate of amylase
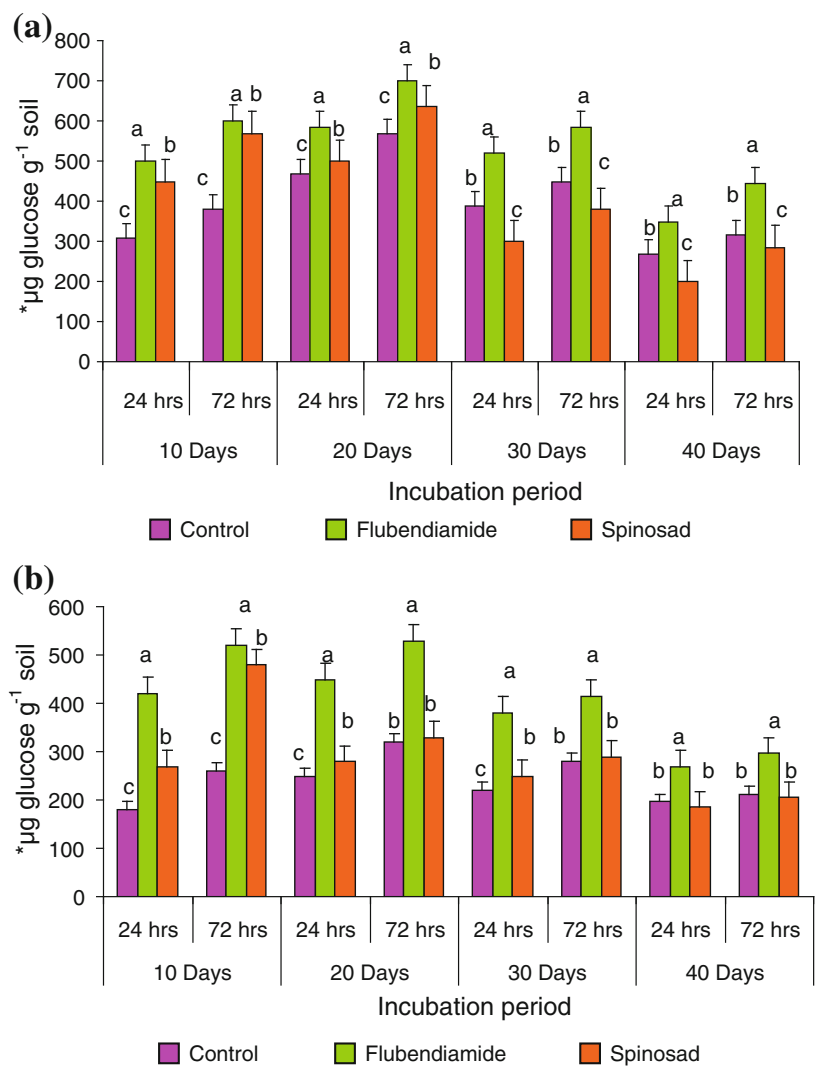

Fig. 3 Influence of flubendiamide and spinosad on amylase*activity in a black clay and b red clay soil at $2.5 \mathrm{~kg} \mathrm{ha}^{-1}$. ${ }^{*} \mu \mathrm{g}$ glucose per gram soil formed after 24 and $72 \mathrm{~h}$ incubation with $2 \%$ starch. The values are the mean $\pm \mathrm{SE}$ for each incubation period, are not significantly different $(P \leq 0.05)$ from each other according to Duncan's multiple range (DMR) test

activity followed the same trend of initial stimulation followed by inhibition as reported by Rangaswamy and Venkateswarlu (1992) and Vijay Gundi et al. (2007). Thus, far, no information has been available regarding the influence of flubendiamide and spinosad on these soil 
enzyme activities. At the same time, much more should be done to understand the influence of flubendiamide and spinosad on soil enzymes clearly. Hence further investigation is needed to evaluate the influence of insecticides on the enzyme activities in agricultural soils which are important and affect nutrient cycling and fertility of soils.

\section{Conclusions}

Results from this study indicated that the cellulase enzyme activity was profoundly increased up to $2.5 \mathrm{~kg} \mathrm{ha}^{-1}$ where as at higher concentrations $\left(5.0-10.0 \mathrm{~kg} \mathrm{ha}^{-1}\right)$ of pesticide concentration the enzyme activity were dramatically decreased in both the soils except spinosad at $5.0 \mathrm{~kg} \mathrm{ha}^{-1}$ in red clay soil. Invertase enzyme activity was decreased from $5.0-10.0 \mathrm{~kg} \mathrm{ha}^{-1}$ level when compared to control in black clay soil where as the enzyme activity at $1.0-2.5 \mathrm{~kg} \mathrm{ha}^{-1}$ level. In red clay soil the invertase enzyme activity was stimulated up to $10.0 \mathrm{~kg} \mathrm{ha}^{-1}$ when compared to control except fubendiamide for $48 \mathrm{~h}$ and for spinosad for $24 \mathrm{~h}$ at $7.5-10.0 \mathrm{~kg} \mathrm{ha}^{-1}$. Amylase enzyme activity showed a stimulatory activity up to $5.0 \mathrm{~kg} \mathrm{ha}^{-1}$ further increase in the pesticide concentration repression in the enzyme activity was noticed in both soils. Overall soil enzymes were affected by the application of flubendiamide and spinosad at higher concentrations (5.0-10.0 $\left.\mathrm{kg} \mathrm{ha}^{-1}\right)$. However, as an important agent for the control of plant pathogens, flubendiamide and spinosad is often used at rates much greater than the recommended dosage.

Overall, flubendiamide and spinosad at a normal field dose (1.0-2.5 $\mathrm{kg} \mathrm{ha}^{-1}$ ) would not pose a threat to soil enzymes among them spinosad is more effective than flubendiamide in inducing the cellulase and invertase with exception of amylase enzyme activities at normal field rates $\left(1.0-2.5 \mathrm{~kg} \mathrm{ha}^{-1}\right)$. When flubendiamide and spinosad concentration was increased $\left(5.0-10.0 \mathrm{~kg} \mathrm{ha}^{-1}\right)$, however, the threat to soil, cellulase, invertase and amylase increased. A very few reports are available on the influence of insecticides on these enzyme activities cellulase, invertase, and amylase.

Acknowledgments The authors are grateful to the University Grants Commission UGC-SAP, New Delhi, India, for financial assistance (UGC S.LR. No. F.3-25/2009) and at the same time we are very much thankful to the Department of Microbiology, Sri Krishnadevaraya University for providing all the necessary facilities in fulfilling our research.

Conflict of interest The author(s) declare(s) that there is no conflict of interests regarding the publication of this article.

Open Access This article is distributed under the terms of the Creative Commons Attribution License which permits any use, distribution, and reproduction in any medium, provided the original author(s) and the source are credited.

\section{References}

Alexander M (1961) Introduction to soil microbiology. Wiley Estern Ltd, New Delhi

Anonymous (2011) Agriculture production plan for Anantapur District, Andhra Pradesh, India. Department of Agriculture, Anantapur, Andhra Pradesh, India

Arinz AE, Yubedee AG (2000) Effect of fungicides on Fusarium grain rot and enzyme production in maize (Zea mays L.). Glob J Appl Sci 6(4):629-634

Barnes H, Folkard BR (1951) The determination of nitrite. Analyst 76:599-603

Bera SK, Dash P, Singh SP, Dash MM (2002) Bacterial Pod rot: a new threat to groundnut under rice-based cropping system in Orissa, India. Int Arac News Lett 22:40-41

Bhalerao TS, Puranik PR (2009) Biodegradation of organochlorine pesticide, endosulfan, by a fungal soil isolate, Aspergillus niger. Int Biodeterior Biodegrad 59:315-319

Bhuyan S, Sau S, Adhya K, Sethunathan TK (1992) Accelerated aerobic degradation of $\gamma$-hexaclorocyclohexane in suspensions of nonflooded soils pretreated with hexaclorocyclohexane. Biol Fertil Soils 12:279-284

Chu XF, Hua P, Xuedong W, Xiao S, Bo Min F, Yunlong Y (2008) Degradation of chlorpyrifos alone and in combination with chlorothalonil and their effects on soil microbial populations. J Environ Sci 20:464-469

Cole MA (1977) Lead inhibition of enzyme synthesis in soil. Appl Environ Microbiol 33:262-268

Deng S, Tabatabai M (1994) Colorimetric determination of reducing sugars in soils. Soil Biol Biochem 26:473-477

Garcia-Ruiz R, Ochoa V, Vinegla B, Hinojosa MB, Pena-Santiago R, Liebanas G, Linares JC, Carreira JA (2009) Soil enzymes, nematode community and selected physico-chemical properties as soil quality indicators in organic and conventional olive oil farming: influence of seasonality and site features. Appl Soil Ecol 41:305-314

Gherbawy YA, Abdel Zaher HMA (1999) Isolation of fungi from tomato rhizosphere and evaluation of the effect of some fungicides and biological agents on the production of cellulose enzymes. Czech Mycol 51:157-170

Gianfreda L, Rao MA, Piotrowska A, Palumbo G, Colombo C (2005) Soil enzyme activities as affected by anthropogenic alterations: intensive agricultural practices and organic pollution. Sci Total Environ 341:265-279

Gigliotti C, Allievi L, Salandi C, Ferrari F, Farini A (1998) Microbiol ecotoxicity and persistence in soil of the herbicide bensulfuron methyl. J Environ Sci Health 33(4):381-398

Hegde DM, Kiresur V (1999) Oilseeds. Changing paradigms. In: Venkataramani G (ed) Survey of Indian agriculture. The Hindu, Chennai, pp 67-72

Ismail BS, Fugon D, Omar O (1996a) Effect of metolachlor on soil enzymes in Malaysian soil. J Environ Sci Health 31(6):1267-1278

Ismail BS, Omar O, Ingon O (1996b) Effects of metolachlor on the activities of four soil enzymes. Microbios 87(353):239-248

Ismail BS, Yapp KF, Omar U (1998) Effects of metsulfuron methyl on amylase, urease and protease activities in two soils. Aus J Soil Res 36:449-456

Jackson ML (1971) Soil chemical analysis. Prentice Hall India, New Delhi

Jaya Madhuri R, Rangaswamy V (2002) Influence of selected insecticides on phosphatase activity in groundnut (Arachis hypogaea L.) soils. J Env Biol 23(4):393-397

Johnson CM, Ulrich A (1960) Determination of moisture in plant tissues. Calif Agric Bull 766:112-115 
Katayama A, Kuwatsuka S (1991) Effects of pesticides on cellulose degradation in soil under upland and flooded conditions. Soil Sci Plant Nutr 37:1-6

Kennedy ZJ, Arathan SS (2002) Influence of carbofuran on the activity of soil enzymes in submerged rice soil ecosystem. In: Rajac RC (ed) Biotechnology of microbes and sustainable utilization. India, pp 322-326

Kirst HA, Michel KH, Mynderse JS, Choco EH, Yao RC, Nakatsukasa WM (1992) Discovery, isolation and structure elucidation of a family of structurally unique fermentation derived tetracyclic macrolides, in synthesis and chemistry of Agrochemicals III. In: Basker DR, Fenyes JG, Steffens JJ (eds) American Chemical Society, Washington, pp 214-215

Kiss S, Dragan-Bularda M, Radulescu D (1978) Soil polysaccharidases: activity and agricultural importance. In: Burns RG (ed) Soil enzymes. Academic Press, London, pp 117-147

Loganathan M, Sundara babu PC, Balasubramanyam G (2002) Efficacy of biopesitcides against Spdeoptera litura (Fab.) on groundnut (Arachis hypogaea L.). Mad Agric J 89(7-9):521-524

Megharaj M, Venkateswarlu K, Rao AS (1989) Interaction effects of insecticides combinations towards the growth of Scenedesmus bijugatus and Synechococcus elongates. Plant Soil 114:159-163

Megharaj M, Singleton I, Kookana R, Naidu R (1999) Persistence and effects of fenamiphos on native algal populations and enzymatic activities in soil. Soil Biol Biochem 31:1549-1553

Menon P, Gopal M, Prasad P (2004) Influence of two insecticides chloripyriphos and quinolphos on arginine ammonification and mineralizable nitrogen in two tropical soil types. J Agric Food Chem 24(52):7370-7376

Menon P, Gopal M, Prasad P (2005) Effects of chlorpyrifos and quinalphos on mineralization in soils of diverse genesis under differing management systems. Biol Fertil Soils 27:430-438

Mohiddin GJ, Srinivasulu M, Madakka M, Rangaswamy V (2010) Influence of insecticides on the activity of amylase and cellulase in groundnut (Arachis hypogaea L.) soil. Ecol Environ Conserv 3(16):383-388

Mohiddin GJ, Srinivasulu M, Madakka M, Rangaswamy V (2011) Influence of selected insecticides on enzyme activities in groundnut (Arachis hypogaea L.) soils. Dyn Soil Dyn Plant 1(5):65-69

Moorman TB (1989) A review of pesticide effects on microorganisms and microbial processes related to soil fertility. J Prod Agric 2(1):4-23

Nelson N (1944) A photometric adaptation of Somogyi method for determination of glucose. J Biol Chem 153:375-380

Prasad BN, Mathur SN (1983) Effect of metasystox and cumin-1 on seed germination, reducing sugar content and amylase activity in Vigna mungo (L.) Hepper. Ind J Plant Physiol 2(24):209-213

Quazi S, Datta R, Sarkar D (2011) Effects of soil types and forms of arsenical pesticide on rice growth and development. Int $\mathrm{J}$ Environ Sci Technol 8:445-460

Ramesh Babu K, Santharam G, Chandrasekharan S (2002) Bioefficacy of imidacloprid against leaf miner Aproaerema modicella deventor on groundnut (Arachis hypogaea L.). Pestology 6(26): $13-16$

Ramudu AC, Mohiddin GJ, Srinivasulu M, Madakka M, Rangaswamy V (2011) Impact of fungicides chlorothalonil and propiconazole on microbial activities in groundnut (Arachis hypogaea L.) soils. ISRN Microbiol, p 7

Rangaswamy V, Venkateswarlu K (1992) Activities of amylase and invertase as influenced by the application of monocrotophos, quinalphos, cypermethrin and fenvalerate to groundnut soils. Chemosphere 25(4):525-530

Ranney TA, Bartlett RJ (1972) Rapid field determination of nitrate in natural waters. Commun Soil Sci Plant Anal 3:183-186

Sannino F, Gianfreda L (2001) Pesticide influence on soil enzymatic activities. Chemosphere 45:417-425
Singaram P, Kamalakumari K (2010) Effect of continuous application of different levels of fertilizers and farm yard manure on enzyme dynamics of soil. Mad Agric J 87:364-365

Singh J, Singh DK (2005) Bacterial, azotobacter, actinomycetes, and fungal population in soil after diazinon, imidacloprid, and lindane treatments in groundnut (Arachis hypogaea L.) fields. J Environ Sci Heal B 40(5):785-800

Singh BK, Kuhad RC, Singh A, Lal R, Triapthi KK (1999) Biochemical and molecular basis of pesticide degradation by microorganisms. Crit Rev Biotechnol 19:197-225

Skujins J (1978) History of abiotic soil enzyme research. In: Burns RG (ed) Soil Enzyme. Academic Press, London, pp 1-49

Srinivasulu M, Rangaswamy V (2006) Activities of invertase and cellulase as influenced by the application of tridemorph and captan to groundnut (Arachis hypogaea) soil. Afr J Biotechnol 2(5): $175-180$

Srinivasulu M, Mohiddin GJ, Rangaswamy V (2012) Effect of insecticides alone and in combination with fungicides on nitrification and phosphatase activity in two groundnut (Arachis hypogaea L.) soils. Environ Geochem Health 3(34):365-374

Stratton GW, Corke CT (1982a) Toxicity of the insecticide permethrin and some degradation products towards algae and cyanobacteria. Environ Poll Ser A 29:71-80

Stratton GW, Corke CT (1982b) Comparative fungitoxicity of the insecticide permethrin and ten degradation products. Pestic Sci 13:679-685

Swaminathan P, Prabharan D, Uma L (2009) Fate of few pesticides metabolizing enzymes in the marine Cyanobacterium Phormidium Valderianum BDU 20041 in perspective with chlorpyrifos exposure. Pestic Biochem Physiol 94:68-72

Tejada M (2009) Evolution of soil biological properties after addition of glyphosate, diflufencian and glyphosate + diflufencian herbicides. Chemosphere 76:365-373

Tohnishi M, Nakao H, Furuya T, Seo A, Kodama H, Tsubata K, Fujioka S, Kodama H, Hirooka T, Nishimatsu T (2005) Flubendiamide, a novel insecticide highly active against lepidopterous insect pests. J Pestic Sci 30:354-360

Truu M, Truu J, Ivask M (2008) Soil microbiological and biochemical properties for assessing the effect of agricultural management practices in Estonian cultivated soils. Eur J Soil Biol 44:231-237

Tu CM (1981a) Effect of pesticides on activity of enzymes and microorganisms in a clay loam soil. J Env Sci Health 16:179-181

Tu CM (1981b) Effect of some pesticides on enzyme activities in an organic soil. Bull Environ Contam Toxicol 27:109-114

$\mathrm{Tu}$ CM (1982) Influence of pesticides on activities of amylase, invertase and level of adenosine triphosphate in organic soil. Chemosphere 2:909-914

Tu CM (1988) Effect of selected pesticides on activities of amylase, invertase and microbial respiration in sandy soil. Chemosphere 17:159-163

Tu CM (1995) Effect of five insecticides on microbial and enzymatic activities in sandy soil. J Environ Sci Health 30:289-306

United States Department of Agriculture (USDA) (2011) Foreign Agricultural Service (FAS)

Vijay Gundi AKB, Viswanath B, Subhosh Chandra M, Narahari Kumar V, Rajasekhar Reddy B (2007) Activities of cellulose and amylase in soils as influenced by insecticide interactions. Ecotoxicol Environ Safety 68:278-285

Yang CL, Sun TH, He WX, Zhou QX, Chen S (2007) Single and joint effects of pesticides and mercury on soil urease. J Environ Sci 19(2):210-216

Zabaloy MC, Garland JL, Gomez MA (2008) An integrated approach to evaluate the impacts of the herbicides glyphosate, 2,4-D and metsulfuron-methyl on soil microbial communities in the Pampas region, Argentina. Appl Soil Ecol 40:1-12 